\title{
Farmer Interest Groups: an effective pathway for enhancing agricultural production, productivity and profitability
}

\section{BS Khadda, K Lata, R kumar, AK Rai, S Khajuria, YG Patel, SK Varia \& AD Rathva}

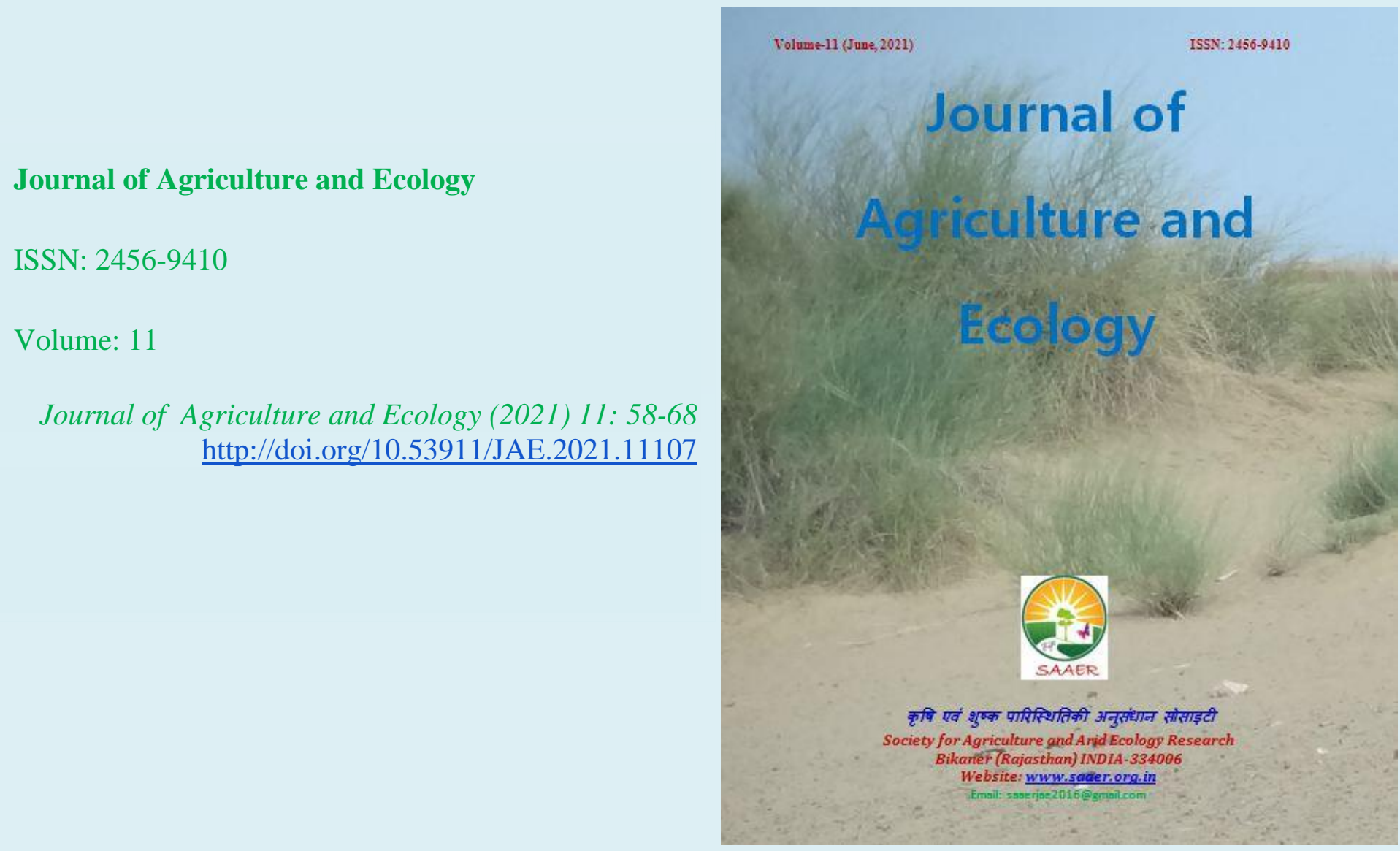




\title{
Farmer Interest Groups: an effective pathway for enhancing agricultural production, productivity and profitability
}

\author{
BS Khadda ${ }^{1} \not$, K Lata, R kumar ${ }^{1}$, AK Rai ${ }^{1}, \mathrm{~S}$ Khajuria ${ }^{1}$, YG Patel ${ }^{2}$, SK Varia ${ }^{3} \&$ AD Rathva ${ }^{3}$ \\ ${ }^{1}$ ICAR- Krishi Vigyan Kendra- Panchmahal, (CIAH) Vejalpur, Godhra, (Gujarat) 389340 \\ ${ }^{2}$ Deputy Project Director, ATMA Project, Panchmahal \\ ${ }^{3}$ Block Technology Manager, ATMA Project, Panchmahal \\ $\square$ Corresponding author: BS Khadda, E-mail: khadda74@gmail.com
}

\section{Article Info}

Article history

Received: 21 May 2021

Accepted: 25 June 2021

Available online: 30 June 2021
Key Words: Adoption, crop, dairy farming, fig, impact, respondents.

\begin{abstract}
The present study was conducted to assess the impact of Farmers' Interest Groups on transfer of technologies and enhancing agricultural production, productivity and profitability of farming community of Panchmahal district of central Gujarat, India. For impact assessment study, 10 FIGs were selected randomly from different villages of Kalol and Goghmba taluka of Panchmahal district. The results of present study revealed that the mean adoption level of scientific crop and dairy production technologies was found to be greater (82.53 MPS and 81.51 MPS) for the member of Farmer Interest Groups after technological interventions of KVK, Panchmahal as compared to the non-FIG members (54.47 MPS and 36.65 MPS), respectively. The overall difference in adoption level of scientific crop and dairy farming technologies of FIGs members and non FIG members was found to be 27.98 and 44.87 MPS, respectively. During the period of study, it was observed that the crop and dairy production under FIG recorded the higher yield than existing farmers' practices. The percentage increase in yield was recorded 21.50 percent in milk production of cow to 58.72 percent in lucerne production over existing farmers' practices. Based on the study, it may be inferred that the formation of Farmer Interest Groups (FIGs) has been highly beneficial to farmers. After realizing the benefits of FIGs, the beneficiary members were more active in participation, meetings and adoption of improved agriculture and animal husbandry technologies. Therefore, there is a need to bring out a comprehensive policy with institutional framework and adequate incentives for promotion of FIGs for crops -livestock based farming system in the country which will not only be helpful in agriculture and livestock production but also improve the socioeconomic conditions of the farming community.
\end{abstract}

Copyright (C2021 Khadda et al., This is an open access article published under the terms of the Creative Commons Attribution License, which permits unrestricted use, distribution, and reproduction in any medium, provided the original work is properly cited.

Preferred citation: Khadda BS, Lata K, kumar R, Rai AK, Khajuria S, Patel YG, Varia SK \& Rathva AD. 2021. Farmer Interest Groups: an effective pathway for enhancing agricultural production, productivity and profitability. Journal of Agriculture and Ecology, 11: 58-68; http://doi.org/10.53911/JAE.2021.11107.

\section{Introduction}

Collectivization of farming community, especially small and marginal farmers, into
Farmer Interest Group has emerged as one of the most effective pathways to address the many challenges of agriculture but most 
importantly, improved access to investments, technology and inputs and markets. Collectivization of farmers can be done through mobilizing farmers into groups called Farmer Interest Groups (FIGs), forming Farmer Producer Organizations (FPOs), strengthening farmers' capacity through training on improved agricultural practices for enhancing crop and livestock productivity in sustainable manner, ensuring access to and usage of quality inputs and services, and facilitating access of the producer groups to fair and remunerative markets for marketing the agricultural produce as well as their value added products, where feasible. Farmer Interest Groups are participatory platforms for improving decision making capacity and stimulating local innovation for sustainable agriculture. Farmers' Organizations are seen as a useful organizational mechanism for mobilizing farmers' collective self-help action aimed at improving their own economic and social situation and that of their communities. Such organizations were perceived to have an ability to generate resources from their members. Empowered farmers' organizations in form of SHG, FIG, FPO can act as convergent points or platforms for solving local problems and mobilizing human and financial resources for sustainable development (Manalili 1990). When the farmers are facilitated to organize groups, trained and guided properly, they can attain tremendous development goal which would eventually make the group self- reliant and self sufficient. The establishment of Farmer Interest Groups (FIGs) and farmer's federation helps in gaining the confidence of farmers in the agriculture sector (Singh \& Srinivasan
1998). The Indian government has been promoting FIGs to address the challenges faced by the small and marginal farmers, particularly those to do with enhanced access to investments, technological advancements, and efficient inputs and markets (Hellin et al. 2009 and GOI 2013). Keeping the above facts in view, to enhance production, productivity and profitability of farmers and make them self sufficient, empowered to produce, market their commodities and develop effective linkages with input agencies Farmer Interest Groups was established by ATMA, Panchmahal with collaborations of KVK, Panchmahal.

\section{Materials and Methods}

The impact assessment study on Farmer Interest Groups (FIGs) was conducted at KVK, Panchmahal. Farmer Interest Groups (FIGs) were established by ATMA Project and KVK, Panchmahal in collaborations of, at the village level to provide a platform for knowledge building and sharing on agro ecology where interested farmers of villages meet, interact and find solutions locally. Nine components, i.e. maize, pigeon pea, groundnut, tomato, chilli, brinjal, fodder sorghum, lucerne and dairy were studied. The major constraints faced by the respondents were collected and ranked. Based on the constraints prioritized and to enhance production, productivity and profitability of FIGs members and make them self sufficient following activities like capacity building activities of farmers were undertaken to enhance the skills and knowledge of group members. Based on criteria, the influence of technological intervention on scientific farming system by FIGs members with 
comparisons to non FIGs members with existing farmers' practices was worked out (Table 1).

The need based training programmes, agro-advisory campaign, diagnostic visits were conducted. The front line demonstrations were conducted on different aspects of agricultural activities at some selected FIGs members field to learn the new technologies by "learning by doing". The exposure visits/ field days were arranged to learning the farmers about new technologies by "Seeing is Believing" in different demonstrations plot/ farms. Through collective approach the quality seed and planting materials of different crops and varieties were made available to the farmers. Through this initiative farmers could get good quality seeds of latest variety and getting high yield and good economic return through this. For impact assessment study, 10 FIGs were selected randomly from different villages of Kalol and Goghmba taluka of Panchmahal district. For the evaluation of FIGs, 60 members of 10 FIGs were selected randomly (six members were selected randomly from each FIGs). For the other half of samples (60 non- FIG members) were selected randomly from the villages adjacent to FIGs established villages, where technological intervention were not conducted by KVK and any other institute or organizations. The impact study on adoption level of respondents was conducted on different aspects of agriculture and animal husbandry related to FIGs was assessed. The data were collected through personal contact with the help of well structured interview schedule. The information regarding adoption of improved technologies were recorded on scale point of fully adopted, partially adopted, ready to adopted and not adopted were analyzed with score value of $3,2,1$ and 0 respectively. The gathered data were processed, tabulated, classified and analyzed in terms of mean percent score and ranks in the light of objectives of the study. The MPS of adoption level of the respondents was calculated as total score of the respondents divided by total possible score multiplies by 100 (Rahman 2007). The data related to production, productivity and economics of different farming systems were collected from demonstrations plot/ animal of FIG members and compared with local check of non FIG members. A partial budget analysis measures was used in those items of expenditure and incomes. Therefore, the cost of inputs used in different farming systems has been considered. The cost of labor was not considered for calculation because it was same in both groups as family members were used. The cost of inputs used in different farming systems was calculated on basis of market rate prevalent during the study period. Selling price of agriculture products/ milk/ eggs, etc., received by farmers during study period was calculated. The collected data were subjected to basic statistical analysis as per Snedecor \& Cochran (1994).

Table 1. Criteria under emphasis for technological intervention on different crops and livestock under FIGs and Non- FIGs members' field

$\overline{\text { Component }}$ Criteria - FIGs




\begin{tabular}{|c|c|c|c|}
\hline \multirow[t]{5}{*}{ Crop production } & Varieties & Hyvs suits to this region & Local strain \\
\hline & Type of seed & Certified seed & Unrecognized \\
\hline & Method of cultivation & Scientific & Traditional \\
\hline & INM & $\begin{array}{l}\text { Recommended dose of } \\
\text { manor\& fertilizers }\end{array}$ & $\begin{array}{l}\text { Unbalanced dose of } \\
\text { manor\& fertilizers }\end{array}$ \\
\hline & IPM & Use of IPM Tools & Haphazard use \\
\hline \multirow[t]{9}{*}{ Dairy farming } & Housing & Proper ventilation & Traditional system \\
\hline & & Cleaned regularly & Not followed \\
\hline & Breed & Pure breeds/ Cross breed & Local/ Nondescript \\
\hline & Feeding & Balance ration feeding & Traditional system \\
\hline & & $\begin{array}{l}\text { Mineral mixture feeding } \\
\text { regularly }\end{array}$ & Not followed \\
\hline & & $\begin{array}{l}\text { Green fodder feeding } \\
\text { round the year }\end{array}$ & Only rainy season \\
\hline & & $\begin{array}{l}\text { Drinking clean and fresh } \\
\text { water }\end{array}$ & Not followed \\
\hline & Health management & $\begin{array}{l}\text { Proper dusting, } \\
\text { deworming and } \\
\text { vaccination }\end{array}$ & Not followed \\
\hline & $\begin{array}{c}\text { Clean milk } \\
\text { production practices }\end{array}$ & Followed & Not followed \\
\hline
\end{tabular}

\section{Results and Discussion}

Adoption level of respondents regarding scientific crop production technologies: The results of present study revealed that the mean adoption level of scientific crop production technologies was found to be greater $(82.53 \%)$ for the members of Farmer Interest Groups after technological interventions of KVK, Panchmahal as compared to the non-FIG members (54.47 per cent). The data presented in Table 2 also reveals that the adoption level of FIG members regarding different improved crop production technologies was higher than non- beneficiaries ranging from 15.34 MPS in field preparation to 44.50 MPS in seed rate \& spacing. The significant difference between both the categories of respondents was found in adoption level of all parameters of improved crop production technologies. The overall difference in adoption level of FIG members and non FIG members was found to be 27.98 MPS which was highly significant. The findings are in line with the findings of Kumawat (2008), Patel et.al. (2009) and Meena (2011). It might be due to the fact that continuous contact of beneficiary farmers of FIG with scientists of KVK, Panchmahal during conducting different extension activities like training programmes, advisory services, field visits, field day, diagnostic services and FLDs at their farm has motivated them to acquire knowledge and skills for 
adopting improved crop production income. technologies for maximize their yield and

Table 2. Extent of adoption level of the respondents about crop production technologies

\begin{tabular}{|c|c|c|c|c|c|c|}
\hline \multirow[t]{2}{*}{$\begin{array}{l}\text { S. } \\
\text { No. }\end{array}$} & \multirow[t]{2}{*}{$\begin{array}{ll}\text { Crop } & \text { production } \\
\text { technologies } & \end{array}$} & \multicolumn{2}{|c|}{$\begin{array}{c}\text { FIG-members } \\
\qquad(\mathrm{n}=60)\end{array}$} & \multicolumn{2}{|c|}{$\begin{array}{l}\text { Non-FIG-members } \\
(n=60)\end{array}$} & \multirow[t]{2}{*}{ Difference } \\
\hline & & MPS & Rank & MPS & Rank & \\
\hline 1 & High Yielding Variety & 87.10 & IV & 61.33 & $\mathrm{~V}$ & 25.77 \\
\hline 2 & Field Preparation & 89.00 & II & 73.66 & II & 15.34 \\
\hline 3 & Seed Treatment & 71.53 & $\mathrm{X}$ & 37.00 & IX & 34.53 \\
\hline 4 & Time of Sowing & 96.32 & I & 73.67 & I & 22.65 \\
\hline 5 & Seed Rate \& Spacing & 88.17 & III & 43.67 & VIII & 44.50 \\
\hline 6 & Nutrient Management & 79.33 & VIII & 44.00 & VII & 35.53 \\
\hline 7 & Irrigation Management & 82.33 & $\mathrm{~V}$ & 64.33 & III & 18.00 \\
\hline 8 & Weed Management & 78.11 & VIII & 47.67 & VI & 30.44 \\
\hline 9 & Pest \& disease management & 73.23 & IX & 36.67 & $X$ & 35.56 \\
\hline 10 & Harvesting \& storage & 80.13 & VI & 62.67 & IV & 17.46 \\
\hline \multicolumn{2}{|c|}{ Overall } & 82.53 & & 54.47 & & 27.98 \\
\hline
\end{tabular}

Adoption level of respondents regarding livestock production technologies: The extent of adoption level by FIG beneficiary and non FIG beneficiary farmers was measured for thirteen improved practices of livestock production technologies. The results of present study revealed that the mean adoption level of scientific dairy production technologies was found to be greater $(81.55 \%)$ for the member of Farmer Interest Groups after technological interventions of $\mathrm{KVK}$, Panchmahal as compared to the non-FIGs members ( 36.65 per cent). Table 2 reveals that the FIGs members adopted clean water drinking to dairy animals at the highest extent with MPS 94.00 followed by clean animal shed daily, use clean and hygienic utensils for milking purpose, deworming of milking, reared pure breed/ Cross breed, mineral mixture feeding, vaccination of animals, dusting of animals, ventilation in animal shed, balance ration feeding, treatment of anestrous problems, full hand milking techniques and green fodder feeding with MPS 91.00, 90.67, $90.33,89.33,88.67,81.33,80.33,74.33$, $71.33,70.67,69.33$ and 68.33 , respectively. The overall difference in adoption level of scientific dairy farming technologies of FIGs members and non FIG members was found to be 44.87 MPS which was highly significant and ranging from 14.66 MPS in ventilation in animal shed to 68.34 MPS in feeding mineral mixture to their dairy animals. The results confirm the expected outputs of FIGs approach of increased farmers' capacity for research, innovation and informed decisionmaking subsequently increase in farmer's income as reported by Ash et al. (2000).

Impact on crop production:The data in present study revealed that the production of maize, pigeon pea and groundnut under demonstrations of FIGs was recorded 
significantly higher as compared to farmers' existing practices of non FIG members. During the period of study, it was observed that the maize, pigeon pea and groundnut cultivation under FIG recorded the higher yield $\left(3120,1450\right.$ and $\left.1950 \mathrm{~kg} \mathrm{ha}^{-1}\right)$ than farmers' existing practices $(2175,1002$ and $1420 \mathrm{~kg} \mathrm{ha}^{-1}$ ), respectively of non FIG members. The percentage increase in yield was recorded 43.45, 44.71and 37.32, respectively over farmer's practices of non FIG members. The extension gap in maize, pigeon pea and groundnut production was found to be 945,448 and $530 \mathrm{~kg} \mathrm{ha}^{-1}$, respectively. The main reason of low yield under farmers' existing practices was mainly due to use of poor quality seeds and use of traditional methods of cultivation with inadequate and imbalanced fertilizers and plant protection measures. FIGs members practiced scientific farming with uses of high yielding verities of seed and adopted scientific cultivation practices like line and early time sowing, proper use of manure and fertilizers with time to time and proper weed management. The results clearly prove the foundation of FIG "farmers first" philosophy, which is in direct contrast to the transfer of technology approach. "Farmers first" concept is essential to empower farmers to learn, experimentation and technology generation and decision making (Paredes 2001). These finding are in accordance with the results reported by Chauhan (2012), Yishak Gecho \& Panjabi (2011), Yadav et al. (2013), Khadda et al. (2014) and Singh et al. (2018) reported that an increasing yield in scientific farming system than farmers' existing practices under front line demonstration. Economic analysis of technological interventions on maize, pigeon pea and groundnut revealed that scientific farming system recorded higher gross returns (Rs. 47000, 76845 and $93525 / \mathrm{h}$ ) and net return (Rs. 26500, 56445 and 65925/ h) with higher benefit ratio $(2.29,3.77$ and 3.39), respectively as compared to existing farmers' practices.

Impact on vegetable production: Vegetables are mostly grown for household consumption at small and also for commercial cultivation for selling in local market at remunerative price. The results of present study revealed that the average production of chilly green, brinjal and tomatoes, was recorded 17345, 34450 and $35100 \mathrm{~kg} \mathrm{ha}^{-1}$ under demonstration of FIGs and 13175, 24815and $26350 \mathrm{~kg} \mathrm{ha}^{-1}$ in existing farmers' practices, respectively of non FIG members. The percentage increase in the yield of chilly, brinjal and tomatoes under FIG demonstration plot was recorded $31.65,38.83$ and 33.21 respectively over existing farmers' practices of non FIG members. The extension gap in chilly, brinjal and tomatoes, production was found to be 4170,9635 and $8750 \mathrm{~kg} \mathrm{ha}^{-1}$, respectively. The higher vegetable production in scientific farming system under FIGs members might be due to use of quality planting material and better management practices adopted by the farmers in group approach. The average net return was recorded significantly higher scientific farming system under FIGs than existing farmers' practices of non FIGs members. The results of the present study are in accordance with the findings of Brahma et al. (2010), Patel and Rajput, (2003), Yadav et al. (2013) and Khadda et al. (2014). 
Impact on fodder production: A comparison of productivity levels of fodder crops between scientific farming practices adopted by FIGs members and traditional farmer practices, it was observed that in scientific farming system, the improved variety of fodder sorghum CoFS-29 and lucerne variety Anand3 recorded the highest green fodder yield 51800 and $61213 \mathrm{~kg} \mathrm{ha}^{-1}$, respectively with compared to existing farmers' practices (33400 and $38566 \mathrm{~kg} \mathrm{ha}^{-1}$ ), respectively of non FIGs members. The percentage increase in the yield of fodder sorghum and lucerne under FIG demonstration plots was recorded 55.09 and 58.72, respectively over existing farmers' practices. More or less yield enhancement in different crops in improved farming system has amply been reported by
Kumar et al. (2010) and Dhaka (2010) and Khadda et al. (2014). The data related to economic analysis of fodder sorghum and lucerne presented in Table 5 revealed that an average additional amount of Rs. 35250 and 58150 per ha was incurred from fodder sorghum and lucerne under demonstrations of FIGs members, respectively than existing farmers practices of non FIGs members. The scientific farming under FIGs recorded higher gross returns and net return with higher benefit ratio than existing farmers' practices. The higher additional returns and effective yield obtained under FIGs demonstrations could be due to improved variety, scientific proven technology, non-monetary factors, timely operations of crop cultivation and scientific monitoring.

Table 3. Extent of adoption level of the respondents about livestock production technologies

\begin{tabular}{|c|c|c|c|c|c|c|}
\hline \multirow{2}{*}{$\begin{array}{l}\text { S. } \\
\text { No. }\end{array}$} & \multirow{2}{*}{$\begin{array}{l}\text { Livestock } \\
\text { technologies }\end{array}$} & \multicolumn{2}{|c|}{ FIG-member } & \multicolumn{2}{|c|}{ Non-FIG-member } & \multirow{2}{*}{ Difference } \\
\hline & & MPS & Rank & MPS & Rank & \\
\hline 1 & $\begin{array}{l}\text { Reared pure breed/ Cross } \\
\text { breed }\end{array}$ & 89.33 & $\mathrm{~V}$ & 51.67 & II & 37.66 \\
\hline 2 & Ventilation in animal shed & 74.33 & IX & 59.67 & $\mathrm{I}$ & 14.66 \\
\hline 3 & Clean animal shed daily & 91.00 & II & 47.66 & III & 43.34 \\
\hline 4 & Balance ration feeding & 71.33 & $\mathrm{X}$ & 22.33 & $X$ & 49.00 \\
\hline 5 & Mineral mixture feeding & 88.67 & VI & 20.33 & XIII & 68.34 \\
\hline 6 & Clean water for drinking & 94.00 & $\mathrm{I}$ & 43.33 & VI & 50.67 \\
\hline 7 & Green fodder feeding & 68.33 & XIII & 21.00 & XII & 47.33 \\
\hline 8 & Vaccination of animals & 81.33 & VII & 47.33 & IV & 34.00 \\
\hline 9 & Deworming of milking & 90.33 & IV & 27.67 & IX & 62.66 \\
\hline 10 & Dusting of animals & 80.33 & VIII & 45.67 & $\mathrm{~V}$ & 34.66 \\
\hline 11 & $\begin{array}{l}\text { Treatment of anestrous } \\
\text { problems }\end{array}$ & 70.67 & $\mathrm{XI}$ & 29.67 & VIII & 41.00 \\
\hline 12 & $\begin{array}{l}\text { Use clean and hygienic } \\
\text { utensils for milking purpose }\end{array}$ & 90.67 & III & 38.39 & VII & 52.28 \\
\hline 13 & Full hand milking techniques & 69.33 & XII & 21.67 & $\mathrm{XI}$ & 47.66 \\
\hline \multicolumn{2}{|c|}{ Overall } & 81.51 & & 36.65 & & 42.71 \\
\hline
\end{tabular}


Impact on milk production: The results of the present study revealed that the average milk production of cow and buffaloes was recorded significantly higher 10.40 and 7.26 liter per animal per day, respectively in scientific farming under FIGs as compared to (8.56 and 5.89 liter per animal per day) existing farmer practices, respectively of non FIGs members. The average increase in milk production of cow and buffaloes was recorded 21.50 and 23.26 per cent, respectively in scientific managed dairy animals by FIGs members as compared to traditional system of non FIGs members. The higher milk production of cows and buffaloes might be due to better management of housing, feeding of balance ration, supplementations of mineral mixture and health management practices adopted by the FIG members. The data related to economic analysis of milk production from cow and buffaloes were presented in Table 5 revealed that scientific interventions by KVK under FIGs recorded higher gross returns and net return with higher benefit ratio than traditional way of existing farmer practices of non FIGs members. An average additional amount of Rs.18871 and 27375 was incurred from cow and buffalo per year under demonstrations, respectively than existing farmer practices of non FIGs members. It is quite obvious from the present study that the scientific and suitable managemental practices of dairy animal were found better than the existing farmers' practices. Murai and Singh (2011), Sathiadhas et al. (2003), Yadav et al. (2013), Khadda et al. (2014), Khadda et al. (2016) and Khadda et al. (2019) also reported that the productive performance of cattle depends heavily on the scientific dairy farming practices.

Table 4. Yield and gap analysis of different crops and livestock under FIGs and Non- FIGs members' field

\begin{tabular}{|c|c|c|c|c|c|}
\hline \multirow[t]{2}{*}{ Particulars } & \multirow[t]{2}{*}{ Yield parameter } & \multicolumn{2}{|c|}{ Yield } & \multirow{2}{*}{$\begin{array}{l}\text { Increase in } \\
\text { yield over } \\
\text { EFP }(\%)\end{array}$} & \multirow{2}{*}{$\begin{array}{c}\text { Extension } \\
\text { Gap }\end{array}$} \\
\hline & & $\begin{array}{c}\text { FIGs } \\
\text { Member }\end{array}$ & $\begin{array}{l}\text { Non-FIG } \\
\text { Member }\end{array}$ & & \\
\hline Maize & Grain $\left(\mathrm{kg} \mathrm{ha}^{-1}\right)$ & 3120 & 2175 & 43.45 & 945 \\
\hline Pigeonpea & Grain $\left(\mathrm{kg} \mathrm{ha}^{-1}\right)$ & 1450 & 1002 & 44.71 & 448 \\
\hline Groundnut & Pod $\left(\mathrm{kg} \mathrm{ha}^{-1}\right)$ & 1950 & 1420 & 37.32 & 530 \\
\hline Chilli green & Chilli $\left(\mathrm{kg} \mathrm{ha}^{-1}\right)$ & 17345 & 13175 & 31.65 & 4170 \\
\hline Brinjal & Brinjal $\left(\mathrm{kg} \mathrm{ha}^{-1}\right)$ & 34450 & 24815 & 38.83 & 9635 \\
\hline Tomato & Tomato $\left(\mathrm{kg} \mathrm{ha}^{-1}\right)$ & 35100 & 26350 & 33.21 & 8750 \\
\hline Fodder sorghum & Green fodder $\left(\mathrm{kg} \mathrm{ha}^{-1}\right)$ & 51800 & 33400 & 55.09 & 18400 \\
\hline Lucerne & Green fodder $\left(\mathrm{kg} \mathrm{ha}^{-1}\right)$ & 61213 & 38566 & 58.72 & 22647 \\
\hline Buffalo & MY/D/A (1) & 7.26 & 5.89 & 23.26 & 1.37 \\
\hline Cross breed cow & MY/D/A (1) & 10.40 & 8.56 & 21.50 & 1.84 \\
\hline
\end{tabular}

$*$ Demo $=$ Demonstration, EFP $=$ Existing farmers' practices, MY/D/A= Milk yield/ day/ animal 
Table 5. Economic analysis of different crops and livestock under FIGs and Non- FIGs members' field

\begin{tabular}{|c|c|c|c|c|c|c|c|c|c|c|c|}
\hline \multirow[t]{2}{*}{ Particulars } & \multicolumn{2}{|c|}{$\begin{array}{l}\text { Average cost of } \\
\text { cultivation } \\
\text { (Rs. /ha) }\end{array}$} & \multicolumn{2}{|c|}{$\begin{array}{c}\text { Average gross } \\
\text { returns } \\
\text { (Rs. /ha) }\end{array}$} & \multicolumn{2}{|c|}{$\begin{array}{l}\text { Average net returns } \\
\text { (Rs. /ha) }\end{array}$} & \multirow{2}{*}{$\begin{array}{c}\text { Addit. } \\
\text { cost } \\
\text { (Rs. } \\
\text { /ha) } \\
\text { Demo }\end{array}$} & \multirow{2}{*}{$\begin{array}{c}\text { Addit. } \\
\text { returns } \\
\text { (Rs. } \\
\text { /ha) } \\
\text { Demo }\end{array}$} & \multirow{2}{*}{$\begin{array}{c}\text { Effective } \\
\text { Gain } \\
\text { (Rs. /ha) } \\
\text { Demo }\end{array}$} & \multicolumn{2}{|c|}{ B:C ratio } \\
\hline & Demo & EFP & Demo & EFP & Demo & EFP & & & & Demo & TFP \\
\hline Maize & 20500 & 18600 & 47000 & 31095 & 26500 & 12495 & 1900 & 14005 & 12105 & 2.29 & 1.67 \\
\hline Pigeonpea & 20400 & 18600 & 76845 & 53410 & 56445 & 34810 & 1800 & 21635 & 19835 & 3.77 & 2.87 \\
\hline Groundnut & 27600 & 26900 & 93525 & 66990 & 65925 & 40090 & 700 & 25835 & 25135 & 3.39 & 2.49 \\
\hline Chilli & 65000 & 45000 & 250270 & 145860 & 185270 & 100860 & 20000 & 84410 & 64410 & 3.85 & 3.24 \\
\hline Brinjal & 45000 & 43500 & 188375 & 145860 & 143375 & 100860 & 1500 & 42515 & 41015 & 4.19 & 3.35 \\
\hline Tomato & 45600 & 41800 & 226525 & 172380 & 180925 & 130580 & 3800 & 50345 & 46545 & 4.97 & 4.12 \\
\hline $\begin{array}{l}\text { Fodder } \\
\text { sorghum }\end{array}$ & 30250 & 28900 & 97800 & 61200 & 67550 & 32300 & 1350 & 35250 & 33900 & 3.23 & 2.12 \\
\hline Lucerne & 35600 & 31250 & 157500 & 95000 & 121900 & 63750 & 4350 & 58150 & 53800 & 4.42 & 3.04 \\
\hline Buffalo* & 33580 & 31755 & 118625 & 89425 & 85045 & 57670 & 1825 & 27375 & 25550 & 3.53 & 2.82 \\
\hline Cow* & 33762 & 32485 & 113880 & 93732 & 80118 & 61247 & 1277 & 18871 & 17594 & 3.37 & 2.89 \\
\hline
\end{tabular}

* Rs. per animal, ** Demo- Demonstrations plot of FIG members, EFP- Existing farmers' practices plot of Non -FIG members

\section{Conclusions}

Based on the study, it may be inferred that the formation of Farmer Interest Groups (FIGs) has been highly beneficial to farmers. After realizing the benefits of FIGs, the beneficiary members were more active in participation, meetings and adoption of improved agriculture and animal husbandry technologies. The behavioral changes among selected farmers through group approach with special references to qualitative and quantitative aspects of agriculture and livestock production have depicted a positive trend. The promotion of FIGs and their linking to institutional agencies for input supply, output marketing and technological services delivery would result in improvement in livelihood of farmers, leading to economic sustainability. Therefore, there is a need to bring out a comprehensive policy with institutional framework and adequate incentives for promotion of FIGs for crops livestock based farming system in the country which will not only be helpful in agriculture and livestock production but also improve the socio-economic conditions of the farming community.

\section{References}

Ashby JA, Braun Ann R \& Gracia T. 2000. Investing in Farmers as Researchers: Experience with Local Agricultural Research Committees in Latin America. International Centre for Tropical Agriculture, Cali, Columbia. Pp-199.

Brahma S, Phookan DB, Kachari M, Hazarika TK \& Das K. 2010. Growth, yield and economics of broccoli under different levels of nitrogen fertigation. Indian Journal of Horticulture, 67: 279-82.

Chauhan NM \& Pandya C D. 2012. Impact and yield crack analysis of trainings and FLDs regarding scientific practices of 
Gram. Agriculture Update, 7(3\&4): 199202.

Dhaka BL, Meena BS \& Suwalka RL. 2010. Popularization of Improved Maize Production Technology through Frontline Demonstrations in Southeastern Rajasthan. Journal of Agriculture Science, 1(1): 39-42.

GOI. 2013. Annual report, 2013-2014. Department of agriculture and cooperation, Ministry of agriculture and farmer welfare, Government of India, Krishi Bhawan, New Delhi-110 001.

Hellin J, Lundy M \& Meijer M. 2009. 'Farmer organization, collective action and market access in Meso- America', Food Policy, 34(1): 16-22.

Khadda BS, Lata K, Kumar R., Jadav JK \& Rai AK \& Khajuria S. 2014. Efficacy of technological intervention on production potential of diversified farming system in Panchmahals district, Gujarat. Indian Journal of Agriculture Sciences, 84 (12): 1531-6.

Khadda BS, Lata K, Kumar R, Jadav JK \& Khajuria S. 2016. Effect of supplementary feeding on productive and reproductive performance of milch buffalo and feed economics under field conditions in Panchmahal district of Central Gujarat. Journal of Agriculture and Ecology, 2: 51-56.

Khadda BS, Lata K \& Kumar R. 2019. Efficacy of pashu chocolate on milk production and reproductive performance lactating buffalo under field conditions of semi arid region. Progressive Research - An International Journal, 14 (Special-I): 651-655.
Kumawat SR. 2008. Impact of frontline demonstration on adoption of improved caster production technology. Rajasthan Journal of Extension Education, 16:143147.

Kumar A, Kumar R, Yadav VPS \& Kumar R. 2010. Impact Assessment of Frontline Demonstrations of Bajra in Haryana State. Indian Research Journal of Extension Education, 10(1): 105-108.

Manalili AG. 1990. Community organizing for people's empowerment. A book published by Manila: Kapativan Kaunlaran Foundation. Pp-197.

Meena KC. 2011. An impact assessment of frontline demonstrations (FLDs) on soybean growers, Rajasthan Journal of Extension Education, 19 : 133-138.

Murai AS \& Singh BK. 2011. Differential adoption of scientific dairy farming practices and related constraints. Indian Research Journal of Extension Education 11 (2): 46-9.

Patel N \& Rajput TBS. 2003. Yield response of some vegetable crops to different levels of fertigation. Annals of Agricultural Research, 24: 542-5.

Patel BI, Patel DB, Patel AJ \& Vihol KH. 2009. Performance of mustard in Banskantha district of Gujarat. Journal of Oilseed Research, 26 (Special issue): 556- 557.

Paredes M. 2001. We are like fingers on the same hand: Peasants' heterogeneity at the interface with technology and project intervention in Carchi, Ecuador. (M. Sc., Wageningen University, The Netherlands). 150pp. 
Sathiadhas R. Noble D \& Immanuel S. 2003. Adoption level of scientific dairy farming practices by IVLP farmers in the coastal agro ecosystem of Kerala. Indian Journal of Social Research 44 (3): 24350.

Singh K \& Srinivasan R. 1998. Role of Farmers' Organization in the Context of New Economic Policy with Particular Reference to Agriculture Marketing and Agro- Processing. Indian Journal of Agriculture Marketing, (Conf. Spl.), 12(3):161-164.

Singh D, Choudhary MK, Meena ML \& Kumar C. 2018. Farmer field school: An innovative approach for boosting spice production in semi arid zone. International Journal of Seed Spices, 8(2), July 2018:64-71.

Yadav GS, Chandan D, Datta M, Ngachan SV, Yadav JS \& Babu S. 2013. Comparative evaluation of traditional and improved farming practices in Tripura. Indian Journal of Agricultural Sciences, 83 (3): 310- 14.

Yishak G \& Panjabi NK. 2011. Determinants of adoption of improved maize technology in Damot Gale, Wolaita, Ethiopia. Rajasthan Journal of Extension Education, 19:1-9. 